Studia z Dziejów Średniowiecza nr 21, 2017

\author{
Edward Rymar
}

(Pyrzyce)

\title{
Pomorskie i polskie wątki w działalności i twórczości Johannesa de Kitzschera (ok. 1460/65-1521)
}

Key words: Johannes von Kitzscher (ca. 1460/65-1521), his presence on a pommeranian court and relations with Poland

Joann(es) von Kitzscher (czasem nazwisko zapisywano: Kitscher, Kiczscher, Kytzscher) to saski humanista i polityk z końca XV i pierwszej ćwierci XVI w., doktor obu praw, poeta łaciński, filozof, mówca, właściwie krasomowca (orator). Ma swą ważną pomorską i pewną polską kartę, dzięki którym wzbudza nasze nim zainteresowanie, ponieważ podczas pobytu w Szczecinie na dworze Bogusława X w latach 1498-1504 napisał pierwszy w obszarze Niemiec i Europy Środkowej obszerny utwór dramatyczny osnuty na kanwie pielgrzymki palestyńskiej tego księcia. Po latach, pozostając w służbie saskich Wettynów i brandenbursko-frankońskich Hohenzollernów, posłował w 1512 r. do króla polskiego Zygmunta Starego, wygłaszając przed nim i jego otoczeniem orację polityczna. U schyłku XIX w. doczekał się studium biograficznego prof. Gustawa Baucha z Wrocławia, które do niedawna było o nim głównym źródłem wiedzy ${ }^{1}$. Obecnie o interesującym nas autorze i jego szczecińskim dziele istnieje już nowe studium pióra Karla-Ottona Konowa².

1 G. Bauch, Dr. Johann von Kitzscher Ein meißnischer Edelmann der Renaissance, „Neues Archiv für Sächsische Geschichte und Altertumskunde” 1899, Bd. 20, s. 286-321; krótki biogram zob. B. Wagner, Kit(z)scher Johannes [w:] Lexikon des Mittelalters, Bd. 5, München-Zürich 1991, szp. 1189; o nim też M. Grossmann, Humanism in Wittenberg 1485-1517, Nieuwkoop 1975.

2 O.-K. Konow, Der Humanist und Jurist Dr. Johannes von Kitscher am Stettiner Hof [w:] idem, Bogislaw - Studien. Beiträge zur Geschichte Herzog Bogislaws X. von 
Wspomniane utwory Kitzschera wraz z oracją pogrzebową ku czci Anny Jagiellonki stanowią obecnie rzadkość, wręcz odchodzą w zapomnienie, co również stało się ważnym powodem troski o ich odnalezienie i przypomnienie. Poza tym Kitzscher jest prawdopodobnie autorem pewnego włoskiego utworu z $1497 \mathrm{r}$. sławiącego czyny zbrojne księcia Bogusława w trakcie jego palestyńskiej pielgrzymki.

\section{Pochodzenie. Młodość i kariera naukowa}

Nasz uczony prawnik pochodził ze starej miśnieńskiej rodziny rycerskiej, wiodącej nazwisko zapewne od miejscowości (dóbr rodowych) Kitzscher w rejonie Borna. Jego przodkami byli, jak się zdaje, rycerze Gunther (1215), inny Gunther (1318), Henryk (1350) Kitscherowie ${ }^{3}$. Stamtąd rodzina przeniosła się do Bawarii i na Ślask. Według leksykonu Zedlera z XVII w., nieprzywołujacego jednak źródeł, nasz bohater był synem Jerzego i miał czterech braci: Jerzego i Wolffa, radców elektora saskiego, Hildebranda, książęcego zarządcę domeny w Rosenheim w Bawarii (1513), oraz bardziej znanego Fryderyka, który - podobnie zresztą jak brat Johannes - jest określony jako rodem z Grossenhain, co widocznie było ich rodową posiadłościa. Zimą 1474/75 Fryderyk był immatrykulowany na uniwersytecie w Lipsku, tamże uzyskał licencjat (1478) i stopień magistra (1481), w Sienie doktorat prawa kanonicznego. Następnie - nauczyciel uniwersytecki w Lipsku (1492), dziekan kolegiaty w Wurzen, skąd w 1503 r. przeszedł na prepozyturę kolegiaty Wszystkich Świętych jako wykładowca nowego uniwersytetu w Wittenberdze ${ }^{4}$.

Johannes był od Fryderyka nieco młodszy, bo zimą 1478/79 został przyjęty na studia w Lipsku ${ }^{5}$. Data urodzenia około 1470 r., jak chcieli niektórzy, ${ }^{6}$ jest więc stanowczo zbyt późna, bo w wieku ośmiu lat nie

Pommern um die Wende vom 15. zum 16. Jahrhundert, Siegen 2003, s. 103-134; nowy tekst jego Tragikomedii zob. ibidem, s. 136-157.

3 S. Baudisch, Lokaler Adel in Nordwestsachsen, Weimar-Wien 1999, s. 307.

4 G. Bauch, Dr. Johann von Kitzscher..., s. 286-288. Pokrewieństwo Jana z Fryderykiem dokumentuje wiersz Georgiusa Sibutusa Daripinusa: generoso Friderico de Kitscher u. I. Doctori et consiliario illustr. Ducum Saxonie,, dedykowany Fryderykowi, wyd. drukiem w Lipsku w $1507 \mathrm{r}$.

5 G. Bauch, Dr. Johann von Kitzscher..., s. 287 i nn.; B. Wagner, Kit(z)scher Johannes...; W matrykule uniwersyteckiej odnotowano Großenhain jako jego miejsce pochodzenia.

6 B. Wagner, Kit(z)scher Johannes... 
mógł studiować 7 . Studia miał wnet przerwać, bowiem ojciec wzywał go do pomocy w zarządzaniu rodową posiadłością w Grossenhain. Ale żądny wiedzy syn oparł się woli rodzica i - około 1490 r. - udał się do Włoch, najpierw do Rzymu, gdzie na kilka lat znalazł się w otoczeniu kardynała Ascanio Marii Sforza (ur. 1455 r., zm. 1505 r.), brata ówczesnego księcia Mediolanu, Lodowico il Moro. Został jego radcą prawnym lub kanclerzem. To przesądziło ostatecznie - również wbrew ojcu - najpóźniej wówczas o wejściu do stanu duchownego. Chociaż nieco później, już w Bolonii, zostanie określony kanonikiem w saskim Naumburgu, oznacza to, że prebendę ową posiadł jeszcze podczas pobytu w ojczyźnie albo dopiero dzięki wpływom swego rzymskiego protektora. Ascanio Sforza przed śmiercią opublikował na cześć Joannesa panegiryk, zawierajacy jego charakterystykę: był to - jego zdaniem - człowiek obdarzony niezwykłymi zdolnościami, przemiły, bez uprzedzeń, szczodry i sławny przez liczne zalety, szczególnie przez mądrość, roztropność i pracowitość. Do tego wyposażony w szczęście, blask rodu, znaczenie swych przodków, sławę brata (Fryderyka) ${ }^{8}$.

Po zakończeniu studiów prawniczych, głównie prawa rzymskiego, udał się, chyba w 1496 r., do Bolonii na mater studiorum, sławny tamtejszy uniwersytet, w każdym razie wymienia go tamtejsza księga rachunków wydziału prawa nacji niemieckiej za 1497 r. Na wniosek uniwersyteckich współrodaków został wybrany rektorem na rok 1497/98. W księdze rachunków uniwersytetu za rok 1497 odnotowany jako „magnicifus nobilisque dominus Johannes de Kytscher utriusque universitatis studii Bononiensis rector" ${ }^{9}$. Doktorat obydwóch praw uzyskał w Bolonii 28 kwietnia $1498 \mathrm{r} .{ }^{10} \mathrm{~W}$ ślad za ówczesną humanistyczną modą wyćwiczył się u swego bolońskiego mistrza Filipa Beroalda Starszego w oracjach, sztuce retorycznej. Wtedy powstało też jego pierwsze znane dzieło pt. Dialogus de Sacri Romani Imperii rebus perquam utilis cum epithomatibus historiarum nedum Romanarum sed et extemarum fere omnium, później wydane drukiem w Lipsku (1501/1504) przez Melchiora Lottera. Wyłożył w niej swoją postawę życiową i dał popis

7 G. Bauch, Dr. Johann von Kitzscher..., s. 319, O.-K. Konow, Der Humanist und Jurist..., s. 108.

8 G. Bauch, Dr. Johann von Kitzscher..., s. 289 i nn.

9 O.-K. Konow, Der Humanist und Jurist..., s. 109. Z tytułem „utriusque Collegii Bononiensis Academiae Rector" występuje potem na Pomorzu, co za niejasny uznawał jeszcze F.W. Barthold, Geschichte von Rügen und Pommern, Bd. IV/2, Hamburg 1845, s. 6.

10 G.C. Knood, Deutsche Studenten in Bologna, Berlin 1899, s. 253, G. Bauch, Dr. Johann von Kitzscher..., s. 290. 
wiedzy o rzymskiej i greckiej kulturze, mitologii, historii starożytnej i średniowiecznej Europy, aż po czasy niedawno zmarłego (w 1493 r.) cesarza Fryderyka III i ku chwale panujaccego jego syna Maksymiliana I. Pomieścił to $\mathrm{w}$ formie dialogu prowadzonego $\mathrm{z}$ udziałem zmarłego 17 listopada 1494 r. w wieku 33 lat we Florencji swego przyjaciela Jana Pico z domu panujaccego we włoskiej Mirandoli. Był to zarazem polityczny traktat o współczesnej sytuacji europejskiej ujawniający polityczny talent i zainteresowania oświeconą władzą ${ }^{11}$. To pośrednio zdaje się przemawiać za tym, że Kitzscher przekroczył wówczas 30 lat, zatem urodził się raczej bliżej 1460 niż 1470 r.

\section{Zapoznanie z Bogusławem X w Bolonii}

Bogusław X - zatroskany o rozwój kultury i nauki w księstwie - podczas dwukrotnego pobytu w Italii w toku swej pielgrzymki palestyńskiej (1497-1498) pozyskiwał włoskich uczonych. W Padwie i Wenecji namówił do podróży na Pomorze doktorów prawa Piotra z Rawenny i jego syna Wincentego, którzy zasilą uniwersytet gryfijski. Potem Bogusław, powracając z Rzymu do Szczecina, 31 stycznia 1498 dotarł do Bolonii ${ }^{12}$. Oddajmy głos Tomaszowi Kantzowowi, który w ślad za relacją sekretarza książęcego Marcina Dalmara, pisze o tym tak:

Pod Bolonia wyszedł mu naprzeciw rektor uniwersytetu wraz ze studentami niemieckimi, węgierskimi, polskimi oraz czeskimi i powitawszy księcia świetną łacińską oracja, odprowadził go do zajazdu i obdarzył sarnami, zajaccami i kuropatwami. Nazajutrz pojechał książę konno do kościoła, mając rektora u boku, i wraz ze swą drużyną wzbudził u wszystkich mieszkańców ciekawość wielka i podziw, że tacy to wielcy i dobrze wyrośnięci mężowie. I gościł książę Bogusław u siebie rektora oraz całą szlachtę niemiecka z Bolonii, wszelkie okazując im uszanowanie, co wielce sobie cenili ${ }^{13}$.

11 G. Bauch, Dr. Johann von Kitzscher..., s. 291-300.

12 Zob. E. Rymar, Wielka podróż wielkiego księcia. Wyprawa Bogustawa X pomorskiego na niemiecki dwór królewski, do Ziemi Świętej i Rzymu (1496-1498), Szczecin 2004, s. 180.

13 T. Kantzow, Pomerania. Kronika pomorska z XVI wieku, tłum. K. Gołda, oprac. T. Białecki, E. Rymar, t. 2, Szczecin 2005, s. 102 i nn. Wcześniej spotkanie bolońskie opisał, w sposób bardziej skrócony, M. Dalmer, Beschreibung Herzog Bugslaffen des 10. Peregrination nach dem Heyligen Lande [w:] Thomas Kantzow's Chronik von Pommern in Niederdeutscher Mundart, hg. W. Böhmer, Stettin 1835, s. 319 i nn. 


\section{3ntlito *}

Eeorrio Stetrinéfi. pomeranie. Laffubie Ŝlauozĩ

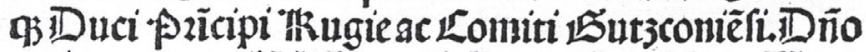

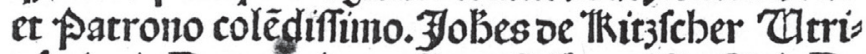

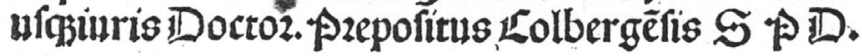

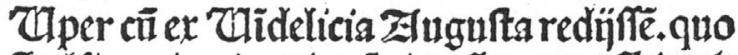
pecelfi genitozis tui noie iueră ozatoz. 夛 ipt3k pagrans. aliq celebzes viri qu vas olĩ mecũ in Ir̆aria paleftra inftructi erät. Officü me gr̆a adiern̈t. Et cũ (ve affolet) inter loquêdũ inuicti tuigenitozis mẽtio incioiffet admurati bois vtutë adbortari vebe mëti'ceperñt comediä oe laubabiliz ftupēda ifta ibe

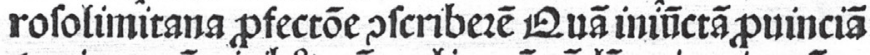
(vt imparẽ virib') aî oeclinarẽ. tãdé ptinaci cosñ et

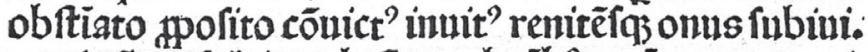
ourinä tis $q b^{\text {"vel }}$ pperã obfequē do volui adeffe: ‘ै pzudēter filẽoo oeeffe. venit ptereaĩ mentẽ ve aiofe frriberë ea.

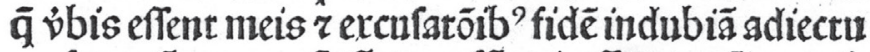

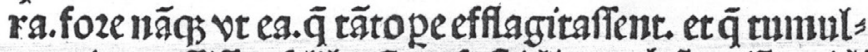
nuarie pgeffiffez. Fellegẽtes faftidire ( ob ieptiä aridi tatēr dicēdi gen?' fimplex) inciperēt. nec vnö in lucē

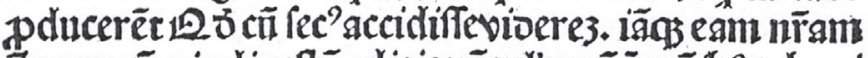

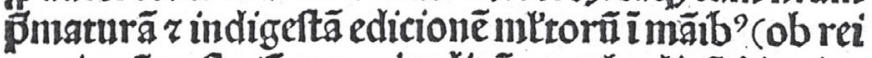
nonitatẽ. geftozin magnitudine er oulcediné bitaris) penerer band qua 9 fufcepti penituit labozis.placuit

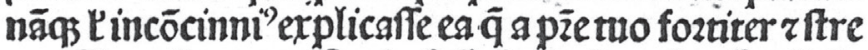
nue für gefta (ne poíteritai tä claris frandare ere

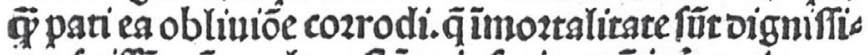

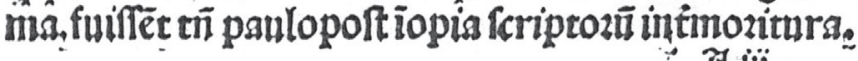
2 iii

Pierwsza strona utworu z 1497 r. (za oryginałem w zbiorach Bibliotheca

Trivulziana, Mediolan) 
Dla studentów nacji niemieckiej i polskich było to wydarzenie. Niosła się po Italii sława księcia pomorskiego, powinowatego polskiego króla, nie tyle z powodu jego pielgrzymki, co krwawych wydarzeń w jej toku, straszliwej bitwy stoczonej z flotyllą turecką przez wenecka galerę pełna pielgrzymów. Gdy potem Bogusław podróżował ze swoimi przez Włochy, był dlatego wszędzie owacyjnie witany, nawet wydano drukiem, być może właśnie w Bolonii, opis wyczynów Gryfity pt. Historia della battaglia data da Turchi con nove vele contra la gallea de pelegrini de l'ano presente MCCCCLXXXXVII ${ }^{14}$.

Na teren Włoch szybko dotarły wieści o tragicznych wydarzeniach u brzegów Peloponezu, o walce pomorskich, polskich, węgierskich, czeskich, niemieckich i szwajcarskich pielgrzymów z flotyllą turecką (30 czerwca 1497 r.). W trakcie przygotowywania kolekcji piśmienniczej Kitzschera podjęto również wysiłek odszukania tego druku. Udało się do niego dotrzeć w bibliotece mediolańskiej, wzbogacając naszą wiedzę o czynach Bogusława X Wielkiego, ale i o utworach literatury pięknej tamtych czasów.

Feta bolońska była tym większa, że owym rektorem był właśnie Kitzscher, o czym tak Dalmer, jak i Kantzow nie napisali ${ }^{15}$. Zapewne owa oracja uczona i kwiecista sprawiła, że Bogusław następnie podczas osobistego spotkania zdołał zachęcić Kitzschera, prawdopodobnego autora czy inspiratora tego włoskiego opisu bitwy, do podjęcia u niego służby państwowej na Pomorzu ${ }^{16}$ i to w nie byle jakim charakterze.

O istnieniu tego włoskiego utworu Emil Motta z Mediolanu poinformował w $1901 \mathrm{r}$. wielkiego pomorskiego historyka Martina Wehrmanna ze Szczecina. W Biblioteca Trivulziana odnotowano wtedy sporządzenie stosownej kopii. Nic mi jednak dotąd nie wiadomo o wykorzystaniu przez Wehrmanna tego tekstu w jego licznych opracowaniach. Na ślad druku nadal przechowywanego w tej mediolańskiej bibliotece natrafiłem w internecie w początkach $2007 \mathrm{r}$. w trakcie przygotowywania do druku piśmiennictwa Jana v. Kitzschera. Zamówiona znów po 106 latach kopia, dzięki uprzejmości pani Isabell Fiorentini z działu starodruków,

14 Emil Motta z Mediolanu ten druk, znajdujący się w Biblioteca Trivulziana w Mediolanie, podesłał w 1901 r. Martinowi Wehrmannowi. Zdołaliśmy i my do niego dotrzeć.

${ }_{15} \mathrm{Na}$ co zwraca uwagę G. Bauch, Dr. Johann von Kitzscher..., s. 301; potem też K.-O. Konow, Martin Dalmer und seine Beschreibung der fahrt Herzog Bogislaws X. in das Heilige Land, BS NF 2001, Jg. 87, s. 78.

16 G. Bauch, Dr. Johann von Kitzscher..., s. 301; K.-O. Konow, Der Humanist und Jurist..., s. 109. 
sporządzona przez Fabio Saporettiego, dotarła do Szczecina w sierpniu $2007^{17}$ i oczekuje na polskie tłumaczenie.

\section{W służbie dworskiej Bogusława X}

W dalszej drodze powrotnej Bogusław gościł 4 kwietnia 1498 r. u swego szwagra, księcia saskiego Jerzego. Kantzow napisał błędnie, że Kitzscher został pozyskany przez Bogusława podczas krótkiego pobytu w Lipsku na dworze szwagra Jerzego saskiego: „Ksiązę Bogusław radował się z księciem Jerzym saskim i dobrej byli myśli oraz wyprosił odeń jednego z jego radców, doktora Jana Kitschera, który wielce uczony był i wymowny [...]"18. Chodziło tymczasem o coś innego, o urlop dla Kitzschera jako poddanego księcia Jerzego, kanonika w Naumburgu, o zgodę na podjęcie pracy na Pomorzu. Kitzscher jeszcze po swoim egzaminie doktorskim (28 kwietnia 1498 r.) odnotowany jest w Bolonii jako rektor ${ }^{19}$. Uwzględniając odległość między Bolonią i Szczecinem (ok. 1400 km) oraz oczywiste odwiedzenie stron rodzinnych i pobyt na dworze księcia saskiego celem otrzymania jego zgody na służbę obcemu władcy, w zamku szczecińskim mógł zameldować się nie wcześniej jak w początkach lipca tego roku ${ }^{20}$. Nie uczestniczył wszak 12 lipca w szczecińskim postępowaniu sądowym, w przesłuchaniu świadków przed: oficjałem i kanonikiem Przybyslawem von Kleistem, Grzegorzem Winolthem klerykiem miśnieńskim, kanclerzem Jerzym von Kleistem i Janem Quentinem - dla udowadniania cudzołóstwa zmarłej w 1489 r. pierwszej żony księcia Bogusława, Małgorzaty brandenburskiej ${ }^{21}$, co przecież musiało być poprzedzone co najmniej kilkutygodniowym przygotowaniem, kiedy Kitzscher był dopiero w drodze na Pomorze ${ }^{22}$.

Główny radca Bogusława „Doctor Johannes von Kitzscher” - jako profesor jurysta i orator aż do roku $1503^{23}$ - pojawia się w najbliższym

17 Znajduje się w zbiorach Książnicy Pomorskiej.

18 T. Kantzow, Pomerania..., s. 105.

19 Acta Nationis Germanicae Vniversitatis Bononiensis, hg. E. Friedlaender, C. Malagola, Berlin 1887, s. 340.

20 K.-O. Konow, Der Humanist und Jurist..., s. 110, gdzie też wykluczono pobytu w Szczecinie 12.07.1498 r.

21 CDBrand., Suplementband, s. 129-131.

22 K.-O. Konow, Der Humanist und Jurist..., s. 110 i nn.

23 Sławi go jako prawnika, oratora, głównego radcę dworskiego przyjaciel dr Wincenty z Rawenny w wierszu dedykacyjnym w Tragikomedii, zob. niżej. 
otoczeniu księcia obok starosty szczecińskiego Wernera von Schulenburga, kanclerza Jürgena von Kleista, szlachciców: Ewalda von Massowa, Doringa von Rahmela, doktorów: Rohra, Beckera, Barnsteina, Swawena, Güntersberga. Już 18 października 1498 r. wraz z biskupem kamieńskim Marcinem Karithem, prepozytem kamieńskim Bernardem Eggebrechtem, marszałkiem ziemi bardzkiej Degenerem von Buggenhagenem, rycerzami Ewaldem von der Ostenem, Piotrem von Podewilsem (Budenwels) i Konradem Krakewitzem, uczestniczył w Barth $\mathrm{w}$ rokowaniach $\mathrm{z}$ pozostającym z księciem w ostrym sporze Berndem von Maltzanem, kiedy to jako rozjemca desygnowany przez króla Maksymiliana wystąpił książę Magnus meklemburski ${ }^{24}$.

Celem zapewnienia należytego utrzymania, warunków materialnych i pozycji w hierarchii kościelnej Bogusław na podstawie świeżo otrzymanego w Rzymie papieskiego przywileju prezentował Kitzschera w 1499 r. na stanowisko prepozyta mariackiej kolegiaty kołobrzeskiej ${ }^{25}$, wraz ze stosowną prebendą większa, co zapewniało mu odpowiednie dochody i pozycję w Kościele pomorskim. Z funkcją prepozyta kołobrzeskiego tradycyjnie było powiązane miejsce w kapitule kamieńskiej. W Kołobrzegu czy w Kamieniu jednak nie przebywał.

Kitzscher odbywał podróże dyplomatyczne w służbie księcia. Pierwsza, do Niderlandów, odbył już w końcu 1498 r. Podczas pobytu króla Maksymiliana w Geldrii Bogusław uzyskał 25 stycznia

24 Urkundensammlung zur Geschichte des Geschlechts von Maltzan, Bd. III, hg. G.C.F. Lisch, Schwerin 1844-1853, s. 292, 296. Kitscher odnotowany na odwrociu dokumentu.

25 H. Hoogeweg, Die Stifter und Klöster der Provinz Pommern, Bd. I, Stettin 1923, s. 327, za J.F. Wachsenem, Historisch-diplomatische Geschichte der Altstadt Colberg, Halle 1767, s. 103 (z data 1499 r.), w każdym razie tego roku otrzymał kołobrzeska prebendę w kolegiacie, zob. H. Heyden, Kirchengeschichte Pommerns, Köln/ Braunsfeld 1957, s. 153. Wcześniej prepozytem był tam Jan Wopersnow (1491-1496), zob. Archiwum Państwowe w Szczecinie, Regesten Bistum. Kammin Orig. Nr 571, 573, 577, Regesten zu den Urkunden das Marienstiftes in Stettin, nr 32. U J.F. Wachsena pod 1496 Wopersnow jest wspomniany tylko jako notariusz, zob. H. Hoogeweg, Die Stifter und Klöster..., s. 371, przyp. 3. W dokumencie z 18 X 1498 r. Kitzscher jest określony tylko jako książęcy radca, chociaż występuje obok kościelnych prałatów, zob. Urkundensammlung zur Geschichte..., s. 292, 296. Potem prepozytem kołobrzeskim był dr Joachim Plate wspomniany dopiero w 1509 r., zob. H. Hoogeweg, Die Stifter und Klöster..., s. 371. Barthold pisze, że w 1499 r. Kitzscher otrzymał prepozyturę po Karicie i miał ją 4 lata, zob. F.W. Barthold, Geschichte von Rügen..., s. 2, co jest błędne, bo Karith był dziekanem, zanim został biskupem w Kamieniu. 
1499 r. potwierdzenie cła wołogoskiego, przywilejów wszystkich swych poprzedników w Rzeszy. Prawdopodobnie z tej okazji Kitzscher wygłosił wcześniej przed królem orację ${ }^{26}$.

Jako radca Bogusława „Doctor Johannes von Kitzscher” wystapił między innymi wraz z biskupem kamieńskim Marcinem Karithem, prepozytem kamieńskim Bernardem Eggebrechtem, marszałkiem ziemi bardzkiej Degenerem Buggenhagenem, rycerzami Ewaldem von der Ostenem, Piotrem von Podewilsem i Konradem Krakewitzem, 18 października 1498 r. w Barth podczas rokowań z pozostającym z księciem w ostrym sporze możnym szlachcicem Berndem Maltzanem, kiedy to jako rozjemca, desygnowany przez króla Maksymiliana, wystapił książę Magnus meklemburski ${ }^{27}$.

Spotykamy go również 11 kwietnia 1499 r. w Szczecinie na czele listy świadków listu lennego dla radcy i kanclerza Jerzego von Kleista na wieś Rzuszcze (Rutze, potem Rüschütz k. Słupska); 4 czerwca tego roku tamże przy zatwierdzaniu przez księcia transakcji tegoż Kleista z Hansem Stojentinem z Górzyna (Goren, potem Gohren k. Słupska), rentmistrzem słupskim, poprzedzając radców, marszałka dworu Piotra Podewilsa i innych dworaków ${ }^{28}$. Wedle dodatku do historii miasta Szczecina P. Friedeborna, wśród dworzan Bogusława X figuruje także „Johan Kitscher doctor” ${ }^{29}$.

Na czele pomorskiego poselstwa Kitzscher udał się w kwietniu 1500 r. na zjazd Rzeszy w Augsburgu, o czym pisze w dedykacji swego wielkiego pomorskiego "tragikomicznego" utworu z $1501 \mathrm{r}^{30}$ Tam wymowny dyplomata zetkną się z żywą ilustracją dla swego Dialogu. Jeden z jego bohaterów, słynny Lodowico il Moro, został właśnie przez króla francuskiego Ludwika XII w sojuszu z Wenecją wypędzony z Mediolanu. Rzesza radziła nad jego restytucja, o co na zjeździe bez rezultatu zabiegał Maksymilian I. Nie wiemy,

26 D. Petrus („Caesar et ipse tue capitur dulcedine linque”, Epigramm. ad Joh. de Kitscher hinter den Opusc. Petri Ravennat), o czym F.W. Barthold, Geschichte von Rügen..., s. 23. Akt Maksymiliana drukował J.K. Dähnert, Pommesche Bibliotek, Bd. I, Greifswald 1750-1756, s. 12.

27 Urkundensammlung zur Geschichte..., s. 292, 296.

28 M. v. Stojentin, Beiträge zur Geschichte des uradeligen Geschlechts von Stojentin pommerschen Ursprungs, Bd. I, Braunschweig 1895, nr 67, 68.

29 P. Friedeborn, Historische Beschreibung der Stadt Alten Stettin in Pommern, Stettin MDCXIII, dodatek ten znajduje się po 4 tablicach genealogicznych, usytuowanych po s.150.

30 „Nuper cum ex Vindelicia Augusta redijssem, quo precelsi genitoris tui nomine iueram orator" (dedykacja w Tragicomedii, 1501 r.). 
jaką tam rolę Kitzscher odegrał. W powrotnej drodze odwiedził w Lipsku starych przyjaciół i towarzyszy ze studiów ${ }^{31}$.

\section{Powstanie Tragikomedii i jej druk}

Kolejny obszerny utwór Kitzschera powstał na dworze szczecińskim jako efekt opowieści księcia i jego otoczenia o perypetiach towarzyszacych pielgrzymce palestyńskiej. To Tragicomedia de iherosolomitana profectione Illustrissimi principis pomeriani etc.Fauerant tibi sidera precor. Finis Tragicomedie prefectionis iherosolimitane Illustrissimi principis Pomeranie. Na karcie tytułowej jest też miejsce, rok wydania (1501) i wydawca: Liptzk per Melchior Lotter impresse Annoxpi millesimo quingentesimo quoque primo.

Wydawcą był Melchior Lotter (też Lotther) Starszy, urodzony w Aue w Vogtlandzie, drukarz w Lipsku, twórca lipskiej oficyny wydawniczej i drukarni już w 1491 r., założyciel słynnego rodu drukarzy w Lipsku, Wittenberdze, Magdeburgu. Poślubił Dorotę, córkę drukarza Konrada (Kunza) Kachelofena (wspomniany w Lipsku 1476 r., zm. w 1528 lub 1529 r.). Już w roku $1484 \mathrm{w}$ Lipsku wyszedł pierwszy druk spod prasy Markusa Brandisa, ale Kachelofen był właściwym, pierwszym drukarzem, który w latach 1485-1499 wydał około 30 druków ${ }^{32}$. Lotter otrzymał 16 czerwca 1498 r. prawo obywatelstwa miejskiego jako „Holzhusen z Wartberg". Pracował zrazu z teściem i potem przejął jego drukarnię. Uprawiał druk łaciński w stylu gotyckim. Jego pierwsze druki wykonane z teściem to m.in.: Joh. Peyligk. Philosophiae naturalis Compendium (1491), Bern. Carthus. Dialogus de immac. concept. B. Virg., Mar. (1493); mszał miśnieński (1495, II wyd. 1500); Secreta sacerdotum Henryka de Hassia (1496); Elegantiarum viginti praecepta (1499); Regulae grammaticales antiquorum (1499). Od 1518 r. zajmował się drukiem pism Marcina Lutra, którego poznał podczas dysputy w Lipsku w roku 1519. Ze starszymi synami, Melchiorem i Michałem, przeniósł się do Wittenbergii, gdzie dotąd działała założona w 1516 r. mała drukarnia Jana Grunenberga. Potem już bez synów powrócił do Lipska, drukując tu do 1528 r., kiedy to prawdopodobnie zmarł. Starszy syn Melchior Młodszy już w 1510 r. miał oficynę w Lipsku, od 1519 w Wittenberdze, gdzie drukował pisma Lutra, w tym

31 F.B. Barthold, Geschichte von Rügen..., s. 31, przyp. 2.

32 Allgemeine Deutsche Biographie [dalej: ADB], Bd. XIV, Leipzig 1875-1912, s. 781. 
poczynając od 1522 r. w jego przekładzie Stary i Nowy Testament. Drukował wiele lat z ojcem, stąd nie mamy jasności, który z nich faktycznie druk wypuścił. Zmarł w roku 1542. Również Michał miał oficynę w Wittenberdze, z bratem w latach dwudziestych, od 1529 r. w Magdeburgu. Zmarł w roku 1554 (1555?). Ten ród drukarzy i teologów był znany jeszcze i w XVIII w. na terenie Niemiec ${ }^{33}$.

Tragikomedia to jeden z najstarszych, a na Pomorzu najstarszy w formie i treści utwór dramatyczny - wzorowany na wcześniejszych pracach Jakuba Lochera i Konrada Celtisa utwór sceniczny, przeznaczony do wystawiania ${ }^{34}$. Ten mało wartościowy jako źródło historyczne druk, infantylny - bo dedykowany siedmioletniemu synowi książęcemu Jerzemu - był w ciagu XVI w. rozchwytywany, ale już w końcu wieku zapomniany i byłby dziś wielce rzadkim, gdyby nie przedruk wykonany po prawie stu latach w $1594 \mathrm{r}$. przez pewnych szczecińskich prawników za egzemplarzem znalezionym we Frankfurcie nad Menem, w formacie B4, bez liczbowania stron. Drugie wydanie przygotowane i wstępem opatrzone przez Bartłomieja Friedeborna ze Szczecina, brata Paula słynnego burmistrza Szczecina i autora historii tego miasta (wydanej w 1613 r.), wydane za sprawą Israela Caykoviusa, sekretarza księcia Jana Fryderyka, w oficynie wydawniczej Joachima Rhetusa ${ }^{35}$. Wydanie z 1594 r., jednak zawierające liczne błędy, znajduje się w kilku bibliotekach niemieckich, w Bibliotece Jagiellońskiej, Bibliotece Uniwersyteckiej we Wrocławiu, ale i w Bibliotece Uniwersytetu Łódzkiego z zasobów dawnej biblioteki zamkowej Ostenów-Bismarcków w Płotach w województwie zachodniopomorskim.

Obecnie Tragikomedia jest drukiem unikatowym. W 2003 r. przedrukował go w nowoczesnej formie Karl-Otto Konow we wspomnianym już studium o autorze ${ }^{36}$. Kolejne wraz z polskim tłumaczeniem Elwiry Buszewicz przygotowała do druku Książnica Pomorska w Szczecinie.

33 J. Franck, Lotter Melchior Starszy [w:] ADB, Bd. XIX, s. 273-275; idem, Lotter Melchior Młodszy [w:] ADB, Bd. XIX, s. 275-277; idem, Lotter Michat [w:] ADB, Bd. XIX, s. 278. Wcześniej ród zaprezentował Karl Lotter [w:] Stammbaum der Familie Lotter in Schwaben, Stuttgart 1879.

34 G. Bauch, Dr. Johann von Kitzscher..., s. 304.

35 Oficyna w początkach XIX w. przeszła na rodzinę Hesselandów, zob. „Monatsblätter” 1887, Jg. 1, s. 11. O wcześniejszych szczecińskich drukarniach od 1569 r. zob. M. Wehrmann, Die ältesten Stettiner Drucke, „Monatsblätter” 1892, Jg. 6, s. 137 i nn.

36 K.-O. Konow, Der Humanist und Jurist..., s. 135-157. 


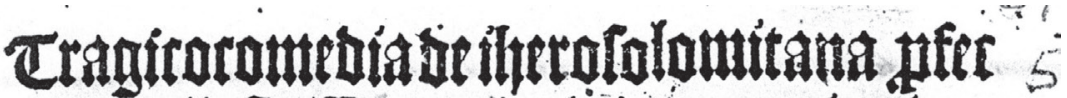

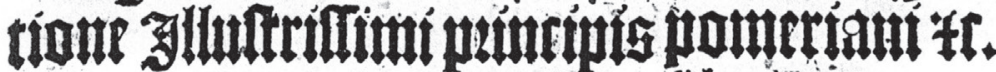 foneant tibi sive}

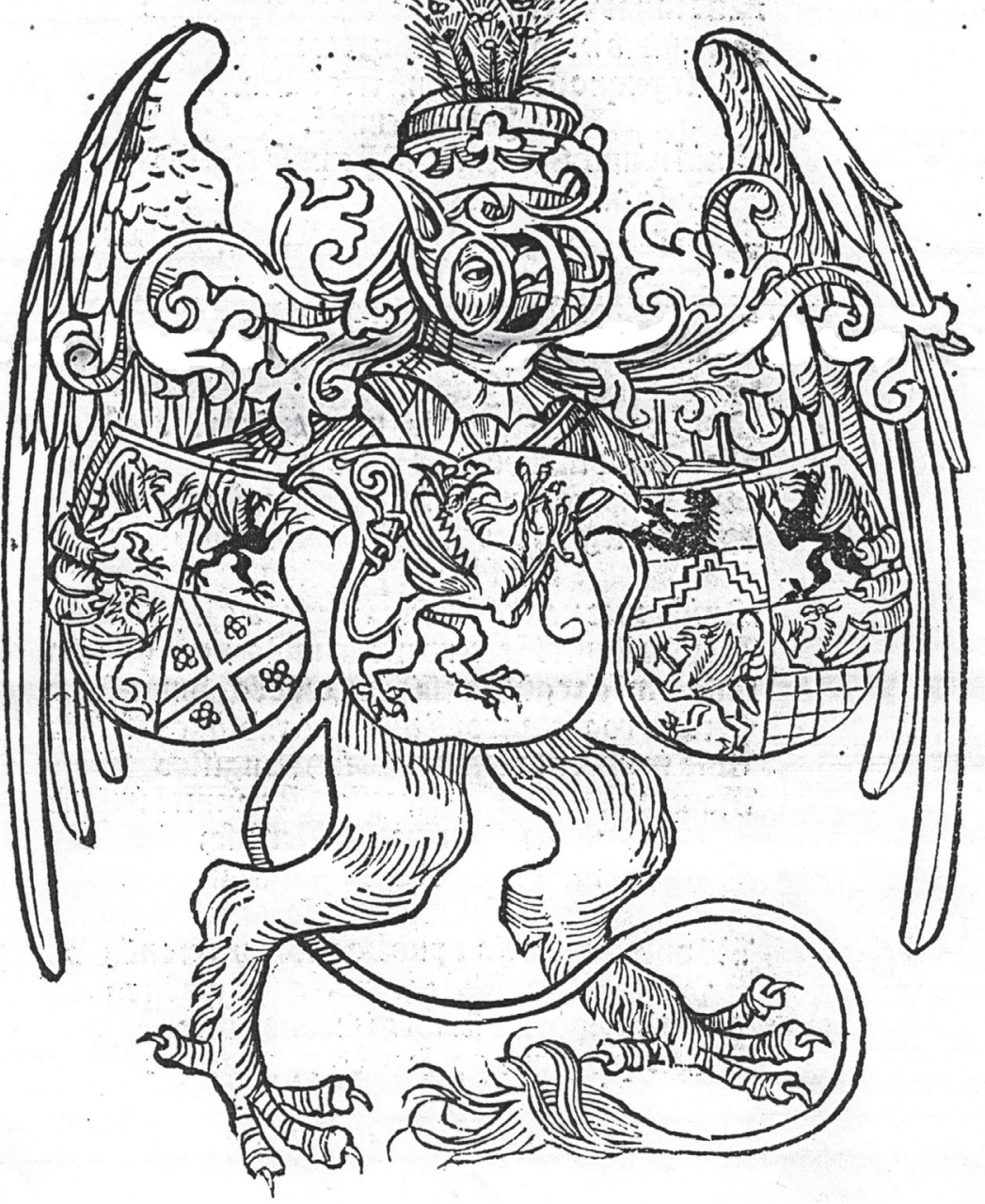

Karta tytułowa pierwszego wydania lipskiej Tragikomedii z 1501 r. (ze zbiorów Staatsbibliothek Bamberg, sygn. BV010047289) 


\section{Pochwała Anny Jagiellonki}

Znane są utwory Piotra i Wincentego z Rawenny świadczące o ich przyjaznych relacjach z Kitzscherem podczas ich wspólnego pobytu na Pomorzu. Takie świadectwo przyjaźni Piotra z Rawenny widać w Aurea opuscula z 1502 r. ${ }^{37}$, gdzie Kitzscher wraz z kanclerzem Jerzym von Kleistem oraz sekretarzem i późniejszym kanclerzem Henningiem Steinwehrem, kanonikiem kamieńskim, otrzymał poetycki panegiryk. Wnet po śmierci Małgorzaty, córki Piotra, Rawennaci opuścili Pomorze, udając się na dwór saski Fryderyka Białego, gdzie wkrótce dołączy Kitzscher.

W 1503 r. Bogusław X pozostawał w ostrym sporze ze Szczecinem. Rokowania, które przyczyniły się do zakończenia sporu, prowadzili radcy dworscy: opat kołbacki Jan, starosta ziemi szczecińskiej Werner von Schulenburg, marszałek ziemi bardzkiej Degener Buggenhagen, dr Jan Kitzscher, marszałek ziemi szczecińskiej Piotr Podewils, kanclerz Henning Steinwehr, doktorzy: Andrzej Becker, Jan Otto, Gaspar von Güntersberg, marszałek dworu Ewald von Massow, ochmistrz księżnej Anny Maciej Lubitzen oraz Vivigenz von Eickstedt ${ }^{38}$. Opat Jan był rozjemca, Kitzscher w hierarchii dworskiej zajmował zatem trzecie miejsce.

Żona Bogusława X Anna Jagiellonka zmarła 12 sierpnia 1503 r. Podobnie jak Wincenty z Rawenny Kitzscher przygotował i wygłosił mowę pogrzebowa, wydaną wraz z Mikołajem Marschalkiem, ćwiartce w Wittenberdze (bez miejsca i roku wydania) ${ }^{39}$ jako Oratio funebris, dedykowana przez Wincentego z Rawenny z listopada 1503 r. (quinto Kal. Novembr.) elektorowi saskiemu Fryderykowi Mądremu. Jej treść była dotąd jednak znana z drugiej ręki. Z mową zapoznał się przed stu laty Bauch na podstawie egzemplarza znajdującego się w bibliotece uniwersyteckiej w Strassburgu i dzięki jego omówieniu mogliśmy

37 Ibidem, s. 308. Pełny tytuł: Aurea opuscula Celeberrimi Juris vtriusque Doctoris et Equitis aurati domini Petri Rauennatis Itali in vniuersitate Gripsualdensi vtrumque Jus ordinarie legentis. Impressa sunt hec Aurea Opuscula In ducali opido Liptzensi per Baccalarium Wolfgangum Monacensem. Anno dominice incarnationis Millesimo quingentesimo secundo (Biblioteka Uniwersytecka we Wrocławiu).

38 T. Kantzow, Chronik von Pommern in niederdeutscher Mundart, hg. O. Gaebel, Stettin 1929, s. 38 i nn.; zob. idem, Pomerania..., t. II, s. 114.

39 Nicolaus Marschalk Thurius, (ur. około 1455), humanista, historyk, doktor na uniwersytecie w Wittenberdze (1504), profesor greki i literatury, założył drukarnię, od 1510 r. na uniwersytecie w Rostoku, zm. w 1525 r., zob. „Neue Deutsche Biographie” 1990, Bd. XVI, s. 252. 
poznać jej treść (zob. fragment obok). Stała się znów okazją do podnoszenia sławy i pobożności polskiej rodziny:

- jej ojca króla Kazimierza IV z powodu czynów, swej pobożności i oddania rzymskiemu Kościołowi, za co zbierał pochwały papieża Piusa II;

- następnie jego synów Władysława, Jana Olbrachta, Aleksandra, zmarłego tego roku kardynała i biskupa poznańskiego Fryderyka, wreszcie księcia Głogowa Zygmunta, późniejszego króla;

- córek króla a sióstr Anny: Elżbiety - żony Jerzego Bogatego księcia bawarskiego ${ }^{40}$, Zofii - żony margrabiego Fryderyka na Ansbach, Barbary księżnej saskiej. Nie zaniedbał pochwały ich matki Elżbiety, wnuczki cesarza Zygmunta i siostry Władysława Pogrobowca króla węgierskiego.

Potem zawarł pochwalę samej Anny, jej całkowite oddanie mężowi, wstydliwość, wstrzemięźliwość, powściagliwość, dobroć, łagodność, łaskawość, jej ochotę do wybaczania, świadczenia dobrodziejstwa, hojności, jej współczucia dla męża, duchowieństwa, rycerstwa, ludu. Wreszcie pocieszał księcia. Obecni byli książęta, biskupi, prałaci, panowie, masy ludu.

Zdaniem Wincentego z Rawenny oracja była mową doskonała w formie. Orator zwraca szczególnie uwagę na szczerą i zupełną miłość księcia do Anny, w przeciwieństwie do pierwszej żony (Małgorzaty elektorówny brandenburskiej). Oracja była w istocie pretekstem, by wygłosić pean ku czci saskiego księcia Fryderyka III Mądrego (1463-1525, elektor od 1486 r.), nowego protektora Rawennatów i Kitzschera. Wincenty z Rawenny pomieścił też w tym druku wiersz żałobny ku czci zmarłej w połogu 12 lipca 1503 r. żony brata elektora Fryderyka - Jana Stałego (1468-1532), księcia saskiego (elektora od 1525 r.), Zofii meklemburskiej, córki Magnusa $\mathrm{II}^{41}$.

Konow, zajmując się twórczością Kitzschera, zwrócił się w styczniu 2003 r. do wspomnianej biblioteki miejskiej w Strassburgu. Agathe Bischoff-Morales z tejże biblioteki poinformowała go, że druku nie ma tak $\mathrm{u}$ nich, jak i w Strassburger Bibliothèque Nationale et Universitaire. Podobnie negatywne były poszukiwania w bibliotece uniwersyteckiej

40 Błędnie, bo chodziło o najstarszą Jadwigę (1457-8.02.1502), od 1475 r. żonę Jerzego (1455-1503) ks. bawarskiego na Landshut.

${ }_{41}$ G. Bauch, Dr. Johann von Kitzscher..., s. 309 i nn.; K.-O. Konow, Der Humanist und Jurist..., s. 133. 
w Lipsku (2 września 2003 r.), Wittenberdze (12 września 2002 r.) i Wolfenbüttel (17 września 2002 r.) ${ }^{42}$. Podjąłem żmudne sprawdzanie innych możliwości w Europie z wykorzystaniem katalogów internetowych. Wreszcie moją uwagę zwróciła Oracio Funebris z bardzo uproszczonym i niepełnym opisem, wskazującym jedynie na objętość (7 kart), format, prawdopodobieństwo wydania około $1506 \mathrm{r}$. i odsyłające do sygnatury w bibliotece w Dessau, mieście kraju związkowego Anhalt.

Doktor Paweł Migdalski, historyk ze Szczecina, bywający często w bibliotece uniwersyteckiej w Greifswaldzie, w toku swych studiów naukowych na moją prośbę poszedł tym tropem, bo czegoż Polak nie zrobi dla chwały Jagiellonów! Po rozszyfrowaniu w Greifswaldzie miejsca, że druk się znajduje w Dessau, nawiązał kontakt z Anhaltische Landesbücherei Dessau - Wissenschaftliche Bibliothek, wcześniej biblioteka księcia Jerzego III von Anhalt na Plötzkau (1507-1553) ${ }^{43}$. Poproszona o sprawdzenie druku Pani Martine Kreißler 13 kwietnia 2007 r. stwierdziła, że rzeczywiście na karcie drugiej jest wymieniony Ioannis de Kitscher, a na karcie trzeciej Anne Stettinensis. Sprawa więc stała się oczywista. Przy okazji dziękuje Pawłowi Migdalskiemu za udział w poszukiwaniach. Potem już rolę swą pełniła Książnica Pomorska, i ta zwróciła się z prośbą o sporządzenie kopii druku, który po 500 latach można będzie dołączyć do przygotowywanej do druku kolekcji piśmienniczej.

42 Bezowocne poszukiwania prowadził niedawno K.-O. Konow, Der Humanist und Jurist..., s. 132, przyp. 479. Nie wyczerpuje to możliwości poszukiwawczych.

43 Rodzina spowinowacona $\mathrm{z}$ dynastią Gryfitów:

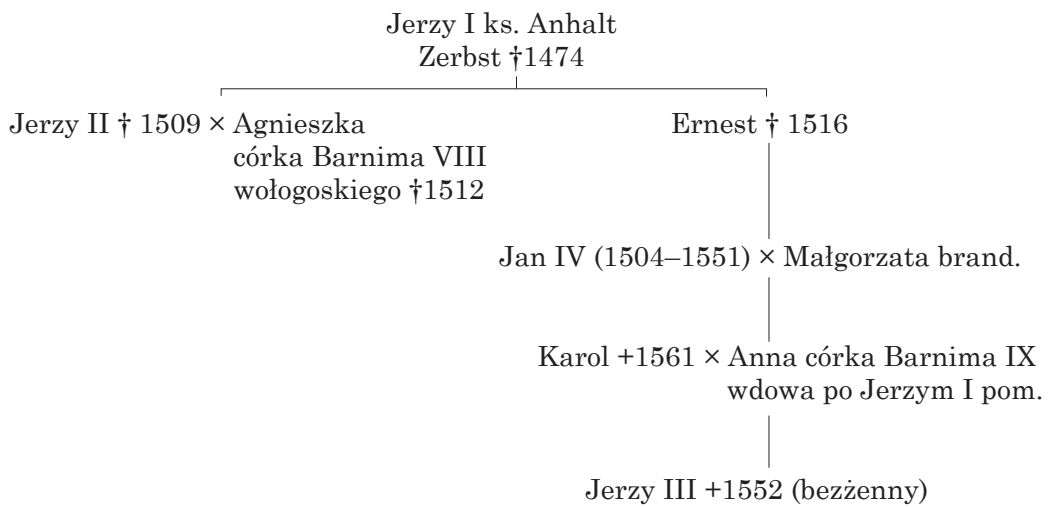


Hiftoria della batraglia daed da rurchi con noue uele côtra lagallea de Pelegrini。 de lano prefente M.ccclisxxiyii.

Ouoi che feti cupidi dal dire

Linfulto facto ala galea fancta

Ad me crederiel uero foui dire

Nellultimo de zugno el di fi canta

Per fignum crucis:o al to crearore

Salua noi dala inimica pianta

Effendo lo fole e marte inferuore

Et lagalea non molto lontana

- Da cauo malio noto á terrore

Alegreto de mente non in fana

Comito degno e apto a tal imprefra

Dife o capitan fe occhi non mingan

Parmi ueder uer noiala diftefa

Venir una armata:er uele pưr afai

Non fo fe fia anica o da offela

Ma in cerreza compagno monierai

Bartolamio lacabia prefto

Er cio dico meglio preńderai

Cofi mixando noi col uolro mefto

Como quelli che fortuna ha morfo

Diceuamo luno a laltro chi equefto

Ecco un uechio pilofo guanto orfo

Gronge elarra:dicoui Calate

Le uof tre welle e che chinate el dorfo

Vn meto

del turcho

Alogran turchoe fue bandere ornate

lo fon de fua genre: 8 bon mellagio

Di quelte fufte qual uedetre armate

Aloife Zorzi Capitano fagio

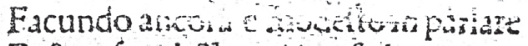

Rifpuole diffe:mai intelo hagio

Chel noltro dominio habi callare

Le fue vele ad Signore alcuno
Mr. Capitisax

mio parla

\section{a}

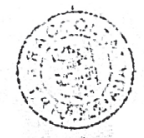

Oracio funebris z 1503 r. (ze zbiorów Anhaltische Landesbücherei Dessau) 


\section{Niefortunny doradca}

Bogusław z wielkiej podróży palestyńskiej przywiózł idee modernizacji państwa, wzmocnienia swej władzy, ograniczenia roli miast. Stąd jesienią 1503 r. wszedł w ostry spór także ze Strzałowem, chcąc ograniczenia praw centrali hanzeatyckiej w Lubece. Do tego doszedł opór miasta przed cłami w Wolgast-Damgarten. Na tym tle w otoczeniu księcia wyklarowały się dwa stronnictwa. Kitzscher stał na czele partii „,jastrzębi”, ostrego kursu, praktyki miśnieńskiej, gdzie miasta - zgodnie ze znanymi włoskimi wzorami - były posłuszne woli swych książąt. Starosta Werner von Schulenburg był za rokowaniami. Kitzscher odegrał niechlubną rolę w zaostrzeniu konfliktu, wręcz wojny księcia z miastem (1503-1504). Po rokowaniach w lutym-sierpniu 1503 r., koncentracji wojsk k. Bardo w sile 1000 jazdy, Bogusław mający sojusznicze stosunki z Danią wypowiedział wojnę hanzeatyckiemu miastu (będącemu w stanie wojny z Dania) i od 5 października 1503 r. zablokował je od lądu. Miasto wypowiedziało księciu wojnę 17 stycznia $1504 \mathrm{rr}^{44}$

Aby zobrazować, jaką rolę odegrał Kitzscher, oddajmy głos Tomaszowi Kantzowowi:

Chciał tedy książę Bogusław załatwić sprawę siłą i oblegać miasto, toteż począ się radzić, jak to uskutecznić. A były dwie zacne strony podczas tej narady, do których się cała przyłączyła reszta. Pierwszą był doktor Kitscher, który wraz ze swą partią radził, iżby wojnę wydać mieszczanom i wreszcie zmusić ich do posłuszeństwa, albowiem rzeczą jest nie do zniesienia, by książę miał pod sobą miasto używające tak niesłusznych i nieznośnych przywilejów i w ogóle czyniące, co mu się podoba. I na poparcie tej rady przytoczył doktor Kitscher przykład miast miśnieńskich, skąd sam pochodził i które wszystko czynić musiały wedle pragnień książąt, partia zaś jego była chętna wojnie, gdyż chciała na niej skorzystać, toteż poparła tę radę. Druga jednak strona, jako to Werner z Schulenburga oraz jego partia, lepsze mając pojęcie o tutejszym kraju niźli doktor Kitscher i własnej nie patrząc korzyści - odradzała wojnę, a to z tej przyczyny, że Strzałów miastem był warownym a potężnym, którego żaden jeszcze książę nie przemógł, ponadto

44 Szczegóły zob. A.T. Kruse, Sundische Studien, Stralsund 1851 („,klocek”, ibidem: II. Erster Entwurf einer Stralsuinder Bürgermeister-Tafel, Stralsund 1846, s. 21 i nn.); F.W. Barthold, Geschichte von Rügen..., s 36-47, M. Wehrmann, Stralsund und Herzog Bogislaw X. von Pommern, BS NF 1934, Bd. 36, s. 129 i nn. 
zaś było w przymierzu z miastami Hanzy. te zaś bez wątpienia po jego stana stronie, jeśli nie otwarcie, to skrycie; mają też strzałowianie tuż za bramami ziemię rugijską i bardzka, toteż jeśli się cokolwiek zrobi przeciw miastu, wnet sobie na tych ziemiach powetuje straty; i jakkolwiek sa tam może ludzie dobrzy i rozumni, to przecie pospólstwo jest niby bestia gniewliwa, co gdy się rozwściekli, to nie zważając na nic, biegnie naprzód i pazurami drze wokół siebie i wali, i niełatwo ją znowu uciszyć; a jeśli książę Bogusław, duże poniósłszy koszty i siebie oraz kraj swój nimi obciążywszy, nic by nie miał wskórać - to skutek będzie taki, że się strzałowian jeno ośmieli tym bardziej i przykład da innym miastom, tak że i one niewiele się będą troszczyły o księcia. Toteż strona ta uważała, iż lepiej dalej pertraktować ze strzałowianami i zobaczyć, czy nie da się chytrością dojść tego, czego nie można siła. Przeciw temu zdaniu doktor Kitscher oraz jego partia wiele wytoczyli argumentów i przymówkę czyniąc do potęgi księcia Bogusława, twierdzili, że skoro tylko strzałowianie ujrza, iż książę coś poważnego przeciw nim zamierza, to nie dopuszcza do tego; ponadto zaś mówili, że jeśli rzeczywiście tak wielkie jest niebezpieczeństwo ze strony miast Hanzy, to książę przecie takoż ma przyjaciół, którzy z pewnością go poprą i udzielą pomocy. I w ten sposób na swoją stronę przeciagnęli księcia Bogusława, który i bez tego skłaniał się ku wojnie. Toteż wypowiedział ją strzałowianom i jesienią 1504 roku stanąwszy w Bardzie, porozsyłał jazdę i knechtów do Gryfii, Łosic, Grzymia [Grimmen], Trzebudzic [Tribsees] oraz wszędzie indziej i pozbawił Strzałów dostaw, a gdzie tylko napotkał strzałowian, tam bił ich oraz chwytał, tak że nikt nie mógł wyjść z miasta. Lecz Werner z Schulenburga uważał, że dobrze się to nie skończy, przeto nie chcąc w tym uczestniczyć ni rada, ni czynem, ruszył do Łeknicy i się o wojnę nie troszczył. A mąż ów się nie pomylił. Mieszczanie bowiem, skoro dławiono ich zewsząd i ani z miasta wyjechać nie mogli, ani doń się dostać, a ludzi ich wszędy łapano i bito - rozjuszyli się i podniósłszy larum, pobiegli na rynek oraz do ratusza, krzyczac, że gwałtu ścierpieć nie wolno, wyjść trzeba z miasta i poszukać księcia oraz jego ludzi. Rajcy ich chcieli uciszyć - niechaj nie będą tak krewcy, zacna rada pomyśli, jak wszelkie sprawy załatwić wedle powinności, napisze do sojuszników i będzie pilnować, iżby nie pozbawiono miasta starych przywilejów oraz uprawnień; niechże jeno mieszczanie powróca do domów i broń swą opatrza, tak by w razie rozkazu byli w gotowości; nie da się radzić z całym tłumem i rozstrzygać w sprawie. Atoli mieszczanie tego nie zrobili i żadnej nie chcąc zwłoki rzekli, iż ruszą wodą oraz lądem i nocą napadną księcia 
w Bardzie lub go tam oblegną miasto Strzałów z pewnością dość ma siły, iżby nie ustapić jakiemuś tam księciu - jak to zwykle plebs prosty gada w takich razach. Był tam jednakże burmistrz stary, pan Samuel [Zabel] Oseborn mąż rozważny i mądry ${ }^{45}$, który z racji cnót swoich i zacności wielkie miał dotąd poważanie i posłuch. Onże poradził mieszczanom, by się uspokoili i nie czynili tego bez rozkazu rady i zastanowienia, i wskazał im powody, dla których czynić tak nie powinni - przed atakiem z lądu powstrzymają ich bowiem jazda oraz knechci, którzy straż trzymają; z wody też się może nie udać, jako że wiatry mogą im przeszkodzić, a jeśli nawet podpłyna na łodziach, to przecie dział na nich nie przewioza, niezbędnych do sprawy, przeto nic nie wskóraja, lecz zostana pobici i wzięci w niewolę; niechaj więc rajców słuchaja, a ci im powiedza, co czynić. Atoli pospólstwo, usłyszawszy to, zakrzyknęło że burmistrz służalcem jest i obłudnikiem i popiera księcia, i nie chce dobremu miastu pozwolić, iżby zacnego dokonało czynu; takiego zdrajce trzeba by z miasta wygnać, niechby wraz z księciem spróbował, co strzałowianie potrafia. I nie chcąc już słuchać burmistrza, całkiem go zagłuszyli. Mimo to wtrąciło się kilku rozumniejszych mieszczan i rzekło, iżby tak nie krzyczeli; posłuchać trzeba i rozważyć to, co powiedział burmistrz, i nie śpieszyć się z czynem; jeśli nie dzisiaj, to jutro wyruszą lub później; czyż nie byłoby niedorzeczne zachowywać się tak, wrzeszczeć i działać bez namysłu i rozwagi, nic przez to nie osiagając prócz głupoty? Lepiej by było, gdyby niektórzy wrócili do swych domów i tam rządzili, gdyż do tej pory szło im to niesporo, niż żeby mieli w sprawach tak ważkich wrzeszczeć i miasto w takie wprowadzić bagno, z którego nigdy się ono może nie wygrzebać. W ten sposób uciszyli rozjuszonych krzykaczy i to uzyskano, że o wszelkim działaniu w tej sprawie rozstrzygać mieli rajcy. Wysłała tedy rada kilka tysięcy mieszczan na ziemię rugijską i siłą tam podporządkowawszy szlachtę całą książęca, miejscowości i chłopów, hołdować sobie kazali i przysięgać - nie tyle, by się mścić na księciu, ile raczej, by mu swoja pokazać potęgę i tym lepszy sprokurować układ. Wielce to rozzłościło księcia Bogusława i kazał jeszcze bardziej wszystkich pilnować gościńców, co jednak strzałowian po pierwszym przestrachu i złości

45 Samuel (Zabel) Oeseborn, krewny Henryka Rubenowa (1450- przed 1526), szlachcic na Mützkow, starszy cechu sukienników (1488, 1490), w radzie już w 1491 r., burmistrz Strzałowa od 1494 r., w 1525 r. ożeniony z siostrą Henninga Mördera (rajcy 1494, burm. 1500-1516). Jego syn Joachim, starszy cechu sukienników (1521-1524), zob. J.G.L. Kosegarten, Geschichte der Universität Greifswald, Greifswald 1856, Th. 1, s. 117; ibidem, Th. 2, s. 90, 121 (nr 96); A.T. Kruse, Sundische Studien..., s. 23, III, s. 22 i nn.) 
niewiele obeszło i pozostali w mieście, a mając pod dostatkiem prowiantów oraz innych najpotrzebniejszych rzeczy, dali znać $\mathrm{w}$ ten sposób, że przez czas jakiś zdzierżą oblężenie. Atoli zaczęło brakować im drewna, które i tak jest tam drogie; tego jednakże nie dali znać po sobie.

Siedział tedy książę Bogusław z wojskiem swoim w Bardzie oraz w okolicy, nic szczególnego nie wskórał i widząc, że strzałowianie wbrew twierdzeniu doktora Kitschera nie dali się nastraszyć, nie wiedział, co począć dalej - jeśliby wespół z wojskiem dłużej miał tam siedzieć, kosztowałoby to wiele pieniędzy i trudu; jeśliby natomiast pójść miał pod miasto, żeby je zdobywać, to koszty byłyby jeszcze znacznie większe i pewnie nawet $\mathrm{z}$ wieloma tysiącami ludzi miasta by nie zdobył; jeśliby zaś po prostu miał odmaszerować, byłoby to nie tylko haniebne dla niego, ale i w innych jego miastach wielkie spowodowałoby nieposłuszeństwo. Posłał przeto do Wernera z Schulenburga, iżby ten zechciał przybyć i poradzić w sprawie. A skoro tylko przybył, doktor Kitscher, widząc, że jego własna rada na złe się obróciła - nie czekał, aż się Werner pojawi, lecz ruszył skrycie do Miśni i nigdy już nie wrócił ${ }^{46}$.

Tak więc, gdy bezsilny Bogusław uznał, że Kitzscher podsuną mu fałszywą radę, aby postępował twardo i zdecydowanie, bo mimo wielkich kosztów i trudów poniósł ogromne straty, posłał po pomoc do Łeknicy po będącego w niełasce Wernera. Wedle nieco późniejszej relacji dobrze zorientowanego strzałowianina Jana Berckmanna, w jego kronice dolnoniemieckiej z XVI w., przybycie starosty szczecińskiego Wernera ośmieliło opozycję wobec Kitzschera na dworze i podczas kolejnej narady w Barth podniosła głowę, a dr Piotr Podewils, starosta Dymina, miał szyderczo pod adresem Kitzschera powiedzieć: „Strzałów nie jest motylkiem, gdy strzałowianie wylatuja, to wylatuja jak pszczoły z ula; skoro on [tj. Kitzscher] to przyrządził, niechaj to teraz zje”, co oznacza w wolnym tłumaczeniu współczesnym tyle co: „skoro nawarzył piwa, niechaj je wypije"47. I zawstydzony Sas opuścił

46 Fragment w tłum. Krzysztofa Gołdy. Cały opis zob. T. Kantzow, Pomerania..., s. $118-119$.

${ }_{47}$ Chronik Johann Berckmann vom Jahre 1194 bis 1560 [w:] Stralsundische Chroniken, hg. Mohnike und Zober, Th. 1, Stralsund 1833, s. 15 („Herr Doktor, habt Ihr Eure Sache wohl ausessen und gegen die Sundischen ausrücken! Sundt ist neen offenoge, wenn se vth then, so then se vth alß de immenn vth dem rumpe; hebbe gy jdt nhu woll angerichtett, so mogę gy jt vth ethenn”, co w górnoniemieckim brzmiałoby: „Sund ist kein Ochsenauge, wenn się aus sind, so sind wie die Innen aus dem Rumpf, hat er es nun wohl angerichtet, so moege er es ausessen”, tłum. K. Gołda). 
swe miejsce w radzie, wkrótce też skonfundowany prepozuturę i kraj pomorski opuścił ${ }^{48}$.

To było przyczyna zmiany warty przy księciu. Po opuszczeniu dworu przez Kitzschera Bogusław pod wpływem powracającego do łask Schulenburga doprowadził do rokowań i kompromisu ze Strzałowem. Nie mogąc ścisnąć miasta nawet oblężeniem, w obliczu pustoszenia Rugii przez strzałowian, posłuchał rad Wernera i podjął 14 lutego 1504 r. rokowania rozpoczęte w Rostoku, prowadzone pod kierunkiem Schulenburga z udziałem rozjemców, książąt Baltazara i Henryka meklemburskich, Gaspara Ganz na Putlitz posła elektora brandenburskiego Joachima I. Układ pokojowy ze Strzałowem zawarto 3 marca 1504 r. w Rostoku. Zabiegały o to miasta hanzeatyckie: Lubeka, Hamburg, Rostok, Wismar i Lüneburg, śląc posłów do Bogusława ${ }^{49}$.

Kantzow tak podsumował rolę Kitzschera w tej strzałowskiej awanturze:

Która to historia niechaj uwidoczni, jak bardzo szkodliwi są nierozważni doradcy lub tacy, co kraju nie znaja; jak wiele potu przyczyniają i książętom, i poddanym oraz jak ludzie rozumni wszystko z kolei mogą naprawić, o ile we właściwym się pojawią czasie Skoro bowiem książę Bogusław tak daleko w tę wojnę wciagnięty został przez doktora Kitschera oraz jego partię, to nie mógłby jej haniebnie zaprzestać, lecz musiałby jej wszystkie swe poświęcić siły, niezależnie od tego, jaki byłby wynik. I gdyby zwyciężył - przywiódłby miasto do zguby; gdyby zaś przegrał - sam byłby zgubiony, a obie te rzeczy nie byłyby dobre dla kraju. I jeden jedyny Werner z Schulenburga odmienił to dobra rada, tak mianowicie, że sprawa znośna się stała potem dla stron obu, jakkolwiek z początku nieco uciążliwa zdała się strzałowianom. Widać też z tej historii, jak to gmin bezrozumny i wściekły zawsze bez rozwagi działa oraz bez porady, w pogardzie mając i prześladując ludzi rozumnych i zacnych, którzy dobrze mu radza - aż wreszcie z własną szkodą musi się przekonać, że nie ma dobrej głowy, i sprawę oddać musi znowu w ręce rządców rozumnych i zacnych. Dlatego też słuszne jest, iżby baczyć na zacnych, rozumnych i wiernych rajców oraz rządców, iść za ich rada i być im posłusznym; /96/ albowiem jeśli nawet sprawa przy ich radzie nie zawsze pójdzie jak z płatka, to przecie pójdzie lepiej niźli przy radzie nie mającej podstaw ni rozwagi ${ }^{50}$.

48 F.W. Barthold, Geschichte von Rügen...,. s. 43.

49 Zob. M. Wehrmann, Stralsund..., s. 133.

50 T. Kantzow, Pomerania..., t. 2, s. 122. W ślad za tym o znaczeniu Kitschera w wojnie ze Strzałowem napisał w swej kronice z XVI w. J. v. Wedel, Hausbuch des 


\section{Znowu w ojczyźnie}

Kitscher opuścił Pomorze w 1504 r. Nawiąanie kontaktu z dworem elektora saskiego Fryderyka Białego ułatwił mu przebywający tam od 1503 r. Wincenty z Rawenny. Okazję stanowił też nowy uniwersytet w Wittenberdze fundowany w 1504 r. przez Fryderyka. Zachęcano Kitzschera do objęcia tam katedry profesorskiej. Ale ostatecznie nie z uniwersytetem elektor związał swego poddanego. Wzią go do osobistej służby jako sekretarza i kanclerza. W tym charakterze pozostawał do 1508 r. ${ }^{51}$ Stało się to dla Kitzschera okazja do wydania w 1508 r. w Wittenberdze, wraz z Mikołajem Marschalkiem, swojego dedykowanego Fryderykowi Dialogu, w którym nadal mieni się prepozytem kołobrzeskim. Dopiero z 1509 r. pochodzi źródło świadczące o zwolnieniu tamtejszej prałatury ${ }^{52}$. Z lat 1506-1512 wiemy tylko o jego sporze toczonym z Baltazarem hrabia Schwarzburg z otoczenia elektora. W tym też czasie otrzymał prepozyture w Altenburgu ${ }^{53}$. Potem Kitzscher pozostawał w służbie zakonu krzyżackiego i był w 1512 r. jego generalnym prokuratorem w Rzymie ${ }^{54}$.

\section{Przed polskim królem i Sejmem}

Pozostając w służbie elektora saskiego, Kitzscher w 1512 r. posłował na polski dwór od Kazimierza Hohenzollerna margrabiego na Ansbach, syna Fryderyka margrabiego brandenburskiego i Zofii Jagiellonki, która zmarła 5 października 1512 r. Z tej okazji i dla realizacji celów politycznych Kazimierz posłał Kitzschera jako oratora do króla Zygmunta Starego. Podczas posiedzenia Sejmu w Piotrkowie 10 listopada Kitzscher wygłosił mowę. przed królem, jego doradcami i reprezentacją zakonu krzyżackiego. W imieniu Kazimierza połączył się w żałobie z jego wujem Zygmuntem i wyrażał ubolewanie z powodu złych stosunków swego brata Albrechta, wielkiego mistrza zakonu

Herrn Joachim von Wedel auf Krempzow Schloss und Blumberg erbgesessen, hg. J. v. Bohlen Bohlendorf, Stuttgart 1882, s. 21-24.

51 G. Bauch, Dr. Johann von Kitzscher..., s. 311.

52 Ponieważ nie wracał, Bogusław 6.08.1509 r. jego prepozyturę kołobrzeską przekazał doktorowi Joachimowi Platemu, zob. F.W. Barthold, Geschichte von Rügen..., s. 51.

53 G. Bauch, Dr. Johann von Kitzscher..., s. 310-312.

54 O czym H. Freytag, Dr. Johann von Kitzscher im Dienste des Deutschen Ordens, „Neues Archiv für Sächsische Geschichte und Altertumskunde” 1907, Bd. 28, s. 120 i nn. 
krzyżackiego, z Zygmuntem. Kazimierz oferował swe pośrednictwo i prosił króla o stosowne upoważnienie ${ }^{55}$.

Po śmierci wielkiego mistrza Fryderyka saskiego (14 grudnia 1510 r.) dostojnicy krzyżaccy poprosili Albrechta, aby przyjał godności mistrza. Chodziło o to, by przez wybór kolejnego przedstawiciela wysokiego rodu z Rzeszy ochronić zakon przed żądaniami Polski. Dodatkowo Albrecht był bliskim krewnym Zygmunta. 13 lutego 1511 r. został przyjęty do zakonu i następnie w $1512 \mathrm{r}$. legalnie wybrany wielkim mistrzem. Król Zygmunt zaakceptował wybór, ale zaznaczył, że „jeśli Albrecht będzie wypełniał obowiązki wynikajace z traktatu, to zakon znajdzie spokój i łaskę u Niego, w przeciwnym razie odrzuci pokrewieństwo i zbrojnie wymusi na nim ciążący obowiązek". Ale Albrecht dążył do rewizji postanowień traktatu toruńskiego z 1466 r. i do pełnej niezależności zakonu. Na dworze cesarskim zabiegał o pomoc wojskowa Rzeszy na wypadek wojny po odmowie złożenia hołdu i zapewnienie takowe uzyskał ${ }^{56}$. Długo zwlekał z przybyciem do Prus. Kiedy dopiero 22 listopada 1512 r. osiagnął Królewiec, okazało się, że poddani pragną utrzymać pokój, dlatego był zmuszony wejść na drogę rokowań. Posłużył się więc właśnie bratem Kazimierzem. Zygmunt stał mocno na gruncie „wiecznego pokoju” i żadnego pośrednictwa nie chciał. Misja Kitzschera dlatego żadnego efektu nie przyniosła.

Po powrocie Kitzscher swą orację przekazał do publikacji magistrowi Kasprowi Schlickowi, który dedykował ją magistrowi Melchiorowi Freybergerowi, kanonikowi z Freibergu. Tytuł druku, którego egzemplarz znajduje się w bibliotece uniwersyteckiej w Getyndze, brzmi: Oratio ad serenissimum Polonorum Regem habita Petrocouie iiij .idus Novembris.1512. per dominum Joannem de Kitscher Juris utriusque doctorem Et Prepositum Aldenburgensem etc. Lipsig impressit Vuolfgangus monacensis. 1513, a datą dedykacji jest: XIX. Kal. Martii 1513.

Orację poznajemy dzięki korespondencji Kacpra Schlicka z wielkiej rodziny dynastycznej, z której pochodził wcześniej najwybitniejszy ze Schlicków, też Kaspar, zmarły w 1449 r., 1. hrabia Bassano (Passaun), kanclerz Rzeszy z czasów cesarza Zygmunta Luksemburga. Zamieszczamy ją poniżej, w aneksie.

55 G. Bauch, Dr. Johann von Kitzscher..., s. 312.

56 P. Pizuński, Poczet wielkich mistrzów krzyżackich, wyd. II, Skarszewy 1998, s. 150. 


\section{Schyłek i zgon}

Następnie Kitzscher jako generalny prokurator zakonu krzyżackiego miał przebywać w Rzymie, gdzie publikował swe dalsze prace ${ }^{57}$. W 1514 r. pozostawił ślad pobytu w Altenburgu. Około tego czasu zają się badaniami historycznymi Niemiec. Znamy jego list w tej sprawie z 8 maja 1514 r. do elektora saskiego, miłośnika historii, inspiratora badań, w tym przecież i na Pomorzu (stąd jako skutek jego zabiegów o dzieje Pomorza kronika Jana Bugenhagena, 1518 r.). Zwrócił się z prośbą o użyczenie posiadanych kronik węgierskich, czeskich, polskich, szwedzkich, norweskich, duńskich. Elektor odpisał, że posiada tylko niemieckie i mu je udostępnił. Tego roku powstały dwa dalsze alegoryczne utwory w formie dialogu. Jeden datowany na 5 czerwca 1514 r., dedykowany jedenastoletniemu Janowi Fryderykowi, synowi księcia Jana, wydany w 1515 r. w Lipsku u Melchiora Lottera ${ }^{58}$.

Kitzscher nie zmarł w 1515 r., jak napisano na karcie katalogowej Tragikomedii z 1501 r. w bibliotece bamberskiej. Żył w Naumburgu. W początkach $1518 \mathrm{r}$. był bardzo chory ${ }^{59}$. Przed śmiercią został obwiniony przez siostrę bliżej nieznanego Jerzego Kryla o narażenie jej na sromotę. Oświadczał, że jest niewinny. Zmarł 7 lipca 1521 r. w Naumburgu i został pochowany w tamtejszym kościele katedralnym. Brąowa tablica nagrobna w nawie środkowej kościoła z inskrypcją: IOHANNES DE KITZSCHER DOCTOR OVYT ANNO.1.5.2.1.7. IVLY, została w 1747 r. przeniesiona na słup w nawie północnej i w 1997 r. zaginęła ${ }^{60}$.

57 Zob. przyp. 45; tak też B. Wagner, Kit(z)scher Johannes..., s. 1189; G. Bauch nie pisze o tej misji.

58 G. Bauch, Dr. Johann von Kitzscher..., s. 313 i nn. To Virtutis et fortune dissidentium certamen. Leonis pontificis arbitri sententia discussum.Joannis de Kiczscher doctoris J. U. Prepositi Aldenburgen. Etc. Dialogus. Lypsi ex officina Melchiaris Lotteri. Impressit Liptzk Melchiar Lotterus Anno domini. M.CCCC XV

59 G. Bauch, Dr. Johann von Kitzscher..., s. 319 i nn.

60 K.-O. Konow, Der Humanist und Jurist..., s. 117. Wcześniej B. Wagner, Kit(z)scher Johannes..., datuje zgon na około 1521 r., jakby ignorując przekaz G. Baucha. Błędne zatem okazały się dane o działalności Kitschera w latach 1539-1540 jako prokuratora książąt saskich Jerzego i Henryka, zob.G. Bauch, Dr. Johann von Kitzscher..., s. 320 i nn. 


\section{Aneks}

„Nasz Kasper Schlick, magister filozofii, pozdrawia wielce wykształconego męża, Melchiora Freibergera, magistra sztuk wyzwolonych, kanonika freiberskiego, swego przełożonego i zwierzchnika i pisze:

Wpadła mi w ręce, o napełniony wielką kulturą mężu, mowa Jana Kitschera, wielce wykształconego męża naszego wieku, do Najjaśniejszego Króla Polski. Jest napisana tak rozsądnie, uczenie i wytwornie, że może Ci się wydawać, że to mówią same Muzy, albo posłużyła cała literatura łacińska. Sprawiłem, że wyszła ona na widok publiczny i Tobie ją dedykuję, a ty ją weź w objęcia i ucałuj, przyjmij z pogodnym czołem i wyciagniętymi (jak się powiada) rękoma. Uznałem, że nikomu bardziej niż Tobie nie powinna być dedykowana, po czym poznasz moje ku Tobie oddanie.

Bądź zdrów szczęśliwie

Lipsk, 16 lutego 1594.

\section{Mowa do Najjaśniejszego Króla Polski wygłoszona w Piotrkowie 10 listopada 1512 r. przez Johanna von Kitzschera, doktora obojga praw i prepozyta altenburskiego etc.}

Jak wielkim smutkiem i żałoba, Najjaśniejszy Królu, zły los oraz chciwa, okrutna i nielitościwa śmierć dotknęty Kazimierza ${ }^{61}$, twego znakomitego $i$ dostojnego siostrzeńca, można się przekonać choćby na tej podstawie (a ja zamilkne), że zabraty mu przedwcześnie najpobożniejsza rodzicielkę, Najjaśniejsza i niemal święta matronę, Pania Zofię $e^{62}$, wybitna ozdobę, wzór i przykład całej płci niewieściej. Te żałosne $i$ srogie wypadki tak wielce nadszarpnęty ducha $i$ umyst tego znakomitego księcia, że nie przypominat sobie w catym swoim dotychczasowym życiu niczego, co tak by mu zranito serce. Od tej najsmutniejszej śmierci nie minat dzień ani godzina, ani chwila, aby nie tkat on z bólu. Pośród szlochów, wzdychań i zgrzytania zębów sktadat ofiary za śmierć matki, o której wiedziat, że ksiażę do niej tęskni, poddani ja przywotuja, a wszyscy pożadaja jej obecności, ze względu na pobożność $i$ taskawość, uczciwość życia oraz inne światobliwe i niepospolite cnoty, dzięki którym była kochana, czczona i poważana.

61 Kazimierz Hohenzollern (1481-1527), najstarszy syn Fryderyka Hohenzollerna i Zofii Jagiellonki.

62 Zofia Jagiellonka (6.05.1464-5.10.1512), córka Kazimierza Jagiellończyka, siostra Zygmunta Starego, żona Fryderyka Hohenzollerna, margrabiego brandenburskiego na Ansbach (1460-1536). 
Musiałby bowiem przyznać, że jest okrutny i nieludzki, gdyby wśród wspólnej i powszechnej żałoby po tak zastużonej rodzicielce nie odprawit należytych obrzędów i nie okazat potężnego bólu poprzez jasne i wyraźne znaki. Widzisz go zatem, Najjaśniejszy Królu, w czerni, $w \dot{z}$ ałobie, $z$ rozczochranymi włosami obyczajem ludu germańskiego, bez pasa i w mniszej szacie, a przecież obecność tak wielkiego króla powinna go sktonić do tego, by odziat sie purpura $i$ bisiorem i dostojnym złotem oraz uginat się od rozmaitych klejnotów promieniujac ich blaskiem. Lecz wie on, że zarówno radość, jak i smutek, maja swe momenty szczególne, których przestrzeganie jest $w$ tych tu czasach rzecza nie mniej pobożna jak stosowna. Zajaśniała jednak pośród tej największej niedoli $i$ smutku duchowego niemała $w$ tak wielkiej goryczy otucha, która pokrzepia, pociesza i umacnia osłabły umyst: mianowicie, że oglada on Ciebie, swego pana i wuja, catego $i$ zdrowego, szczęśliwego $i$ w dobrym stanie. Prosi przeto w pokornej modlitwie Najlepszego i Najwyższego Boga, aby jak najdtużej tak byto, a nawet coraz lepiej. Przychodzi jednak na myśl wielce udręczonemu i umęczonemu duchowi, że w owej więzi zarówno umystów, jak $i$ krwi istnieja pewne zarzewia czy pobudki, które mogtyby umyst wielce czcigodnego $i$ Najjaśniejszego Księcia Pana, Albrechta ${ }^{63}$, Wielkiego Mistrza pruskiego i najdroższego brata, nie powiem odstręczyć, co ze względu na szacunek stać się nie może, lecz nieco oddzielić. $Z$ tego powodu nie potrafit się nie obawiać, aby z owej maleńkiej iskierki nie wybucht (jak to zwykle bywa) pożar. Pragnac zatem zapobiec, na ile potrafi, zagrażajacemu nieszczęściu, niczego nie uważat za ważniejsze niż to, aby jako tak wielce zwiqzany z jedna $i$ druga strona wptynat na Ciebie, tak aby się to stało nie tylko za Twa aprobata $i$ zgoda, lecz nawet $z$ Twego polecenia. Zatem od tego postanowienia nie odwiodta go wyjatkowość tak srogiego i nieszczęsnego ciosu ani pożałowania godny smutek jego ojca, ani ogrom $i$ waga ciażacych na nim obowiazków, ani spory czas trwania tak dtugiej podróży, ani pokrętne wiry gwattownych rzek, przepaści mostów, odżywajacy na nowo każdego dnia mozót niewyczerpanego trudu, ani szron i mróz nadchodzqcej zimy, ani deszcze, nawatnice $i$ burze, ani odstraszajacy wyglad śniegów $i$ zamarzniętych wód, ani pęd świszczqcych wiatrów, ani tysiqczne niedogodności towarzyszace podróżujacym. Owszem chciat raczej z własnej woli śpiesznie

63 Albrecht Hohenzollern (1490-1568), brat Kazimierza, wielki mistrz zakonu krzyżackiego, potem świecki książę pruski. W latach 1519-1521 prowadził wojnę z Polską. W 1525 r., już jako świecki książę, złożył hołd lenny Zygmuntowi Staremu. 
przybyć, ofiarowujac swe starania, jeśli się na coś w tej sprawie moga przydać. Aby więc taki trud nie okazat się daremny, $i$ aby nie zostaty udaremnione zamiary przedsięwzięte $w$ najlepszej nadziei, prosi jak najusilniej, abyś nie raczył odwracać się od miłego dobrodziejstwa ciszy, spokojności i wytchnienia, a skłonić wojowniczego i przyzwyczajonego do zwycięstw ducha ku dbałości o pokój. W ten sposób niewatpliwie uczynisz rzecz mita Najwyższemu i Nieśmiertelnemu Bogu, a dla chrześcijaństwa zbawienna, korzystna dla wszystkich mieszkańców królestwa, a dla Ciebie szczególnie chwalebna, która nie zaginie nigdy, $w \dot{z}$ adnych wiekach ani innych dłuisszych okresach czasu. Sam zaś przy swej mtodości i wspaniatym umiarkowaniu, tak $w$ niej będzie postepować, by i ci, którzy stusznie szacuja sprawy $i$ ci, którzy niestusznie, jasno zobaczyli, że nie dba on bardziej o cześć, stawe i pożytek ukochanego brata niż o cześć, stawę i pożytek Twej Wysokości i tego wspaniatego Królestwa.

Rzektem.

Drukował Wolfgang z Monachium, w Lipsku 1513 r. (tłum. Elwira Buszewicz, Kraków 2007).

Albrecht pozostał nieprzejednany, prowadził wojenne przygotowania, doprowadzając do wybuchu wojny w 1519 r. Przegrał i 2 kwietnia 1525 r. w Krakowie złożył uroczysty hołd królowi.

\section{Abstract}

\section{Pomeranian and Polish Aspects of the Activity and Work of Johannes de Kitzscher (ca. 1460/65-1521)}

The subject of the author's considerations are the Pomeranian and Polish aspects of the biography and activity of the Saxon humanist, doctor of laws, and orator Johannes von Kitscher (ca. 1460/65-1521). When Johannes von Kitscher was the rector of the university in Bologna (1497), the Pomeranian Duke Bogislaw X, who was traveling through Italy, acquired his services and engaged him to work on his court as a political councillor and diplomat. Performing this function, as well as that of a provost of a collegiate church in Kołobrzeg, he wrote the Tragicomedy, published in 1501 in Leipzig - once renowned dramatic piece based upon 
the Duke Bogislaw's journey to the Holy Land, and in particular the naval battle fought with the Turks on August 30, 1497, off the Peloponnesian coast; a mediocre, childish work, as it was dedicated to the Duke's seven-year-old son, Georg. He also delivered a eulogy during the funeral of the Duke's wife, Anna Jagiellon (1503). As an advocate of a strong-arm regime, he compromised himself as the Duke's councillor during his conflict with the city of Straslund and left Pomerania in 1504. Years later, now in the service of the Hohenzollerns, he delivered a speech before the Polish sejm (1512), enclosed to the paper. 